\title{
Are aquaporin antibody titers useful outcome measures for neuromyelitis optica spectrum disorders?
}

Markus Reindl, PhD

Neurol Neuroimmunol Neuroinflamm 2020;7:e759. doi:10.1212/NXI.0000000000000759

Neuromyelitis optica spectrum disorder (NMOSD) is a rare inflammatory demyelinating disease of the CNS, characterized by an increased risk for severe relapses. ${ }^{1}$ Most patients with NMOSD (>70\%) are seropositive for pathogenic antibodies against the aquaporin-4 (AQP4$\mathrm{Ab}$ ) water channel. Recently, several randomized controlled trials have demonstrated clinical effectiveness of immunosuppressive agents in AQP4-Ab positive NMOSD. ${ }^{2}$ However, a potential biomarker of NMOSD activity that could be measured serially and predicted relapses would assist clinicians in their selection of patients for immunotherapies. A few small observational studies have suggested changes in AQP4-Ab titers as a potential biomarker of NMOSD activity. ${ }^{3,4}$

In this issue of Neurology ${ }^{\circledR}$ Neuroimmunology \& Neuroinflammation, Jitprapaikulsan et al. ${ }^{5}$ provided Class II evidence that neither AQP4-Ab titers nor complement-mediated cell killing has any significant prognostic or predictive utility in NMOSD. The authors have analyzed 336 serial serum samples from $82 \mathrm{AQP} 4-\mathrm{Ab}$ seropositive patients taken preattack, at attack onset, or at remission. $\mathrm{AQP} 4-\mathrm{Ab}$ titers were not significantly changed between the preattack, attack, or remission samples or in those of individual patients during their disease course. Furthermore, maintenance immunotherapy did not significantly affect AQP4-Ab titers. Similarly, the ability of $\mathrm{AQP} 4-\mathrm{Ab}$ for complement-mediated killing in vitro was not influenced by disease activity or treatment. Differences to previous reports reporting conflicting results could be explained by the substantially larger number of patients and samples in this study.

However, the current study of Jitprapaikulsan et al. also had a number of potential limitations, such as its retrospective design, with samples having been collected many years before study (3-14 years), the effect of acute attack immunotherapies given before collection of attack sera, and the experimental setup using 10 -fold dilution for titrations.

Previous studies on the utility of serum levels of autoantibodies in other neurologic autoimmune diseases have shown differential results. In myasthenia gravis, serum titers of acetylcholine receptor antibodies generally vary widely between patients and do not predict disease severity. ${ }^{6}$ By contrast, CSF and, to a lesser degree, serum antibody titers against the NMDA receptor have been associated with a poor outcome in NMDA receptor encephalitis. ${ }^{7}$ There is also conflicting evidence regarding the usefulness of serum antibody titers against the myelin oligodendrocyte glycoprotein (MOG-Ab) which are also present in a subset of AQP4-Ab seronegative NMOSD patients. Some studies have indicated that the clinical recovery or a monophasic disease course is associated with transient MOG-Ab titers, whereas other studies have not been able to confirm these findings. ${ }^{8}$ To summarize, there is controversial evidence about the value of serial serum antibody titers for monitoring disease activity in neurologic autoimmune diseases, which also applies to various other autoantibodies. Possible explanations for these disappointing findings are as follows: first, the limited ability of peripheral blood antibody levels to reflect the situation in the target organ (e.g., the CNS); second, pathogenic

\author{
Correspondence \\ Dr. Reindl \\ markus.reindl@i-med.ac.at
}

\section{RELATED ARTICLE}

\section{Article}

Clinical utility of AQP4-

IgG titers and measures of complement-mediated cell killing in NMOSD

Page e727 
autoantibodies are known to be bound to their target antigens and may therefore not be detectable in the periphery; and finally, in autoimmune encephalitis, CSF autoantibodies levels could be of higher clinical relevance than those found in the serum.,

Therefore, distinct peripheral blood biomarkers such as neurofilament-light or glial fibrillary acid protein are urgently needed and currently under investigation for their prognostic role and their use as therapeutic biomarkers in NMOSD. ${ }^{10}$

\section{Study funding}

No targeted funding reported.

\section{Disclosure}

M. Reindl is supported by a research grant from the Austrian Science Fund (FWF, project P32699). The University Hospital and Medical University of Innsbruck (Austria; employer of M.R.) receives payments for antibody assays (MOG, AQP4, and other autoantibodies) and for MOG and AQP4 antibody validation experiments organized by Euroimmun (Lübeck, Germany). Go to Neurology.org/NN for full disclosures.

\section{Publication history}

Received by Neurology: Neuroimmunology \& Neuroinflammation April 8, 2020. Accepted in final form April 17, 2020.

\section{References}

1. Wingerchuk DM, Banwell B, Bennett JL, et al. International consensus diagnostic criteria for neuromyelitis optica spectrum disorders. Neurology 2015;85:177-189.

2. Hartung HP, Aktas O. Old and new breakthroughs in neuromyelitis optica. Lancet Neurol 2020;19:280-281.

3. Takahashi T, Fujihara K, Nakashima I, et al. Anti-aquaporin-4 antibody is involved in the pathogenesis of NMO: a study on antibody titre. Brain 2007;130:1224-1234.

4. Jarius S, Aboul-Enein F, Waters P, et al. Antibody to aquaporin-4 in the long-term course of neuromyelitis optica. Brain 2008;131:3072-3080.

5. Jitprapaikulsan J, Fryer J, Majed M, et al. Clinical utility of AQP4-IgG titers and measures of complement-mediated cell killing in NMOSD. Neurol Neuroimmunol Neuroinflamm 2020;7:e727. doi: 10.1212/NXI.0000000000000727.

6. Lindstrom JM, Seybold ME, Lennon VA, Whittingham S, Duane DD. Antibody to acetylcholine receptor in myasthenia gravis. Prevalence, clinical correlates, and diagnostic value. Neurology 1976;26:1054-1059.

7. Gresa-Arribas N, Titulaer MJ, Torrents A, et al. Antibody titres at diagnosis and during follow-up of anti-NMDA receptor encephalitis: a retrospective study. Lancet Neurol 2014;13:167-177.

8. Reindl M, Waters P. Myelin oligodendrocyte glycoprotein antibodies in neurological disease. Nat Rev Neurol 2019;15:89-102.

9. Graus F, Titulaer MJ, Balu R, et al. A clinical approach to diagnosis of autoimmune encephalitis. Lancet Neurol 2016;15:391-404.

10. Watanabe M, Nakamura Y, Michalak Z, et al. Serum GFAP and neurofilament light as biomarkers of disease activity and disability in NMOSD. Neurology 2019;93: e1299-e1311. 


\title{
Neurology \\ Neuroimmunology \& Neuroinflammation
}

\author{
Are aquaporin antibody titers useful outcome measures for neuromyelitis optica \\ spectrum disorders? \\ Markus Reindl \\ Neurol Neuroimmunol Neuroinflamm 2020;7; \\ DOI 10.1212/NXI.0000000000000759
}

This information is current as of May 28, 2020

Updated Information \&

Services

References

Permissions \& Licensing

Reprints including high resolution figures, can be found at:

http://nn.neurology.org/content/7/4/e759.full.html

This article cites 10 articles, 1 of which you can access for free at: http://nn.neurology.org/content/7/4/e759.full.html\#\#ref-list-1

Information about reproducing this article in parts (figures,tables) or in its entirety can be found online at:

http://nn.neurology.org/misc/about.xhtml\#permissions

Information about ordering reprints can be found online:

http://nn.neurology.org/misc/addir.xhtml\#reprintsus

Neurol Neuroimmunol Neuroinflamm is an official journal of the American Academy of Neurology.

Published since April 2014, it is an open-access, online-only, continuous publication journal. Copyright

Copyright $\odot 2020$ The Author(s). Published by Wolters Kluwer Health, Inc. on behalf of the American

Academy of Neurology.. All rights reserved. Online ISSN: 2332-7812.

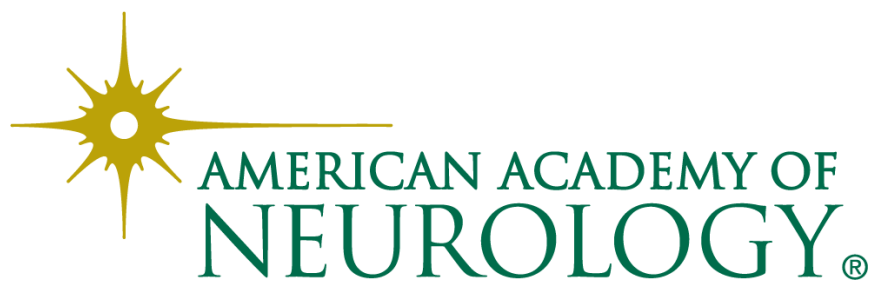

